\title{
Surviving in Changing Seascapes: Sediment Dynamics as Bottleneck for Long-Term Seagrass Presence
}

\author{
Wouter Suykerbuyk, ${ }^{1,2 *}$ Tjeerd J. Bouma, ${ }^{2}$ Laura L. Govers, ${ }^{1}$ Kris Giesen, ${ }^{1,2}$ \\ Dick J. de Jong, ${ }^{3}$ Peter Herman, ${ }^{1,2}$ Jan Hendriks, ${ }^{1}$ and Marieke M. van Katwijk ${ }^{1}$
}

${ }^{1}$ Department of Environmental Science, Faculty of Science, Radboud University Nijmegen, P.O. Box 9010 (Mailbox No. 89), 6500 GL Nijmegen, The Netherlands; ${ }^{2}$ Department of Spatial Ecology, NIOZ Royal Netherlands Institute for Sea Research, 4400 AC Yerseke, The Netherlands; ${ }^{3}$ Zeeland Department, Ministry of Infrastructure and Environment, Rijkswaterstaat, 4330 KA Middelburg, The Netherlands

\begin{abstract}
Changes in the seascape often result in altered hydrodynamics that lead to coinciding changes in sediment dynamics. Little is known on how altered sediment dynamics affect long-term seagrass persistence. We studied the thresholds of sediment dynamics in relation to seagrass presence by comparing sediment characteristics and seagrass presence data of seven separate seagrass meadows. All meadows had a long-term ( $>20$ years) presence. Within these meadows, we distinguish so-called "hotspots" (areas within a meadow where seagrass was found during all mapping campaigns) and "coldspots" (with infrequent seagrass presence). We monitored static sediment characteristics (median grain size, bulk density, silt content) and sediment dynamics (that is, bed level change and maximum sediment disturbance depth), bioturbation (that is, lugworm densities and induced fecal pit and mound relief), and seagrass cover. We statistically analyzed which sediment characteristic best explains seagrass cover.
\end{abstract}

Densely vegetated hotspots were shown to have lower sediment dynamics than sparsely vegetated hotspots and coldspots, whereas static sediment characteristics were similar (grain size, bulk density). The vegetation cover was either low (2-15\%) or high $(>30 \%)$ and sediment dynamics showed a threshold for vegetation cover. From this correlative finding, we postulate a self-sustaining feedback of relatively dense seagrass via sediment stabilization and accordingly a runaway feedback once the seagrass cover becomes too sparse. The sensitivity for sediment dynamics shown in our study implies that future existence of seagrass meadows may be at risk as ongoing climate change might directly (increased environmental extremes) or indirectly (changing seascapes) negatively affect seagrass beds.

Key words: Zostera noltii; seagrass; Arenicola marina; sediment dynamics; sediment stability; persistence; changing seascapes; feedback loops.
Received 26 March 2015; accepted 9 September 2015; published online 20 November 2015

Electronic supplementary material: The online version of this article (doi:10.1007/s10021-015-9932-3) contains supplementary material, which is available to authorized users.

Author contributions Conceived of or designed study: WS, TB, LG, DdJ, PH, MvK. Performed research: WS, LG, KG. Analyzed data: WS, TB, LG, KG, MvK. Wrote the paper: WS, TB, LG, DdJ, PH, JH, MvK.

*Corresponding author; e-mail: wouter.suykerbuyk@gmail.com

\section{INTRODUCTION}

There is an overwhelming body of literature describing the massive and still ongoing losses of seagrass over the last decades, predominantly due to anthropogenic impacts (for example, Orth and others 2006a; Waycott and others 2009). The dominant anthropogenic impacts are related to the 
effects of light limitation, via either enhanced turbidity or eutrophication. A much less studied aspect is the more indirect effect of changes to the coastline due to infrastructural works. Such changes in the seascape may alter natural seagrass structuring processes, and thereby indirectly threaten continued seagrass existence (that is, Lotze and others 2006). Changes in the seascape often result in altered hydrodynamics that in turn lead to changes in sediment dynamics. The direct effects of hydrodynamics and burial processes on short-term seagrass performance are well studied (for example, Fonseca and Kenworthy 1987; Gambi and others 1990; van Katwijk and Hermus 2000; Cabaco and others 2008). In contrast, relatively little is known on how altered sediment dynamics may affect longterm seagrass persistence. This question may be particularly relevant for seagrasses in temperate areas, where plants cannot adapt to burial or erosion during winter when they do not grow (Han and others 2012).

Restoration efforts of seagrass species, particularly Zostera species, have aimed at mitigating the adverse effects of sediment-related processes, either by reducing hydrodynamic forces (van Breedveld 1975; Lewis and others 2006), increasing seagrass anchoring (for example Davis and Short 1997; Fonseca and Bell 1998; Bastyan and Cambridge 2008; Zhou and others 2014), increasing planting density (for example, Bos and van Katwijk 2007) or reducing the adverse effect of bioturbating infauna (Fonseca and others 1995; Hammerstrom and others 1998; Sheridan and others 1998; Hughes and others 2000; Bos and van Katwijk 2007; Suykerbuyk and others 2012), and enhancing sediment stabilization (van Katwijk and Hermus 2000; Campbell and Paling 2003; van Keulen and others 2003; Irving and others 2010).

However, there has been little attention on how sediment dynamics may affect long-term seagrass persistence. In Germany and the Netherlands, temperate intertidal seagrass Zostera noltii is mainly found on intrinsically stable or sheltered sediments (Philippart 1994; Reise and Kohlus 2008; Suykerbuyk and others 2012; Suykerbuyk and others, in press). Sediments are intrinsically stable when they consist of clay-rich and compact remnants of former salt marshes or dikes, or when they consist of a shell layer. In such sediments, lugworm densities are low (Philippart 1994). Sediment dynamics may then be low even if exposure to hydrodynamics is relatively high, and seagrass presence may relate to sediment dynamics even more than to hydrodynamics (van Katwijk and Hermus 2000; Reise and Kohlus 2008). Alternatively, dense seagrass rhi- zomes and roots may stabilize the sediments (Christianen and others 2013) and outcompete the common bioturbator Arenicola marina (Philippart 1994; Berkenbusch and others 2007; Reise and Kohlus 2008; Eklof and others 2011). Arenicola marina is widespread destabiliser of intertidal sandy sediments at northwest European coasts (Cadée 1976; Reise 1985; Coosen and others 1994); its bioturbation hampers Zostera restorations in these areas (Valdemarsen and others 2011; Suykerbuyk and others 2012).

In the Eastern Scheldt tidal basin (SW Netherlands), long-term monitoring of a large-scale seagrass transplantation project clearly indicated winter survival as the main bottleneck for longterm persistence (Suykerbuyk and others 2012; Govers and others 2015; Suykerbuyk and others, in press). Winter losses could not be attributed to adverse negative environmental conditions (for example, nutrients, light availability) as seagrass area expanded during all summers (Suykerbuyk and others, in press). Han and others (2012) showed that erosion or sedimentation events can be quickly counteracted by $Z$. noltii during summer, by growing back to a rooting depth of around $0.6 \pm 0.3 \mathrm{~cm}$. During the stormy winter season, erosion events are however typically more pronounced and more frequent than during summer, and likely to reach deeper than the typical rooting depth. Erosion events above a critical threshold depth may result in uprooting and loss of overwintering seagrass rhizomes, and hence the loss of both transplanted and natural meadows.

We hypothesize that high sediment dynamics reduce winter survival and consequently long-term seagrass persistence, although evidence for the existence of thresholds of sediment dynamics in relation to seagrass presence and insights into how they work are still lacking. Thresholds may be dynamic but site specific, depending on the interaction between local environmental forcing from currents and waves and the susceptibility of the sediment to that force, which depends on the nature of the sediment (that is, packing, cohesiveness, shell content) and the presence of sediment loosening activities (for example, bioturbating infauna). We aim to fill this knowledge gap on thresholds of sediment dynamics in relation to seagrass presence by comparing sediment characteristics and seagrass presence data of seven separate seagrass meadows. All meadows had a longterm (>20 years) presence. Within these meadows, we distinguish the so-called "hotspots" (areas within a meadow where seagrass was found during 
all mapping campaigns) and "coldspots" (areas with infrequent seagrass presence during 19891998, and absence during 1999-2009). Static sediment characteristics (median grain size, bulk density, silt content) were measured in the summer of 2012. Between April 2012 and May 2013, we monitored sediment dynamics (that is, bed level change and maximum sediment disturbance depth), bioturbation (that is, lugworm densities and induced fecal pit and mound relief), and seagrass cover. The resulting dataset was statistically analyzed to identify which sediment characteristic(s) would best explain seagrass cover. We specifically aimed to test the hypotheses that:

H1 Long-term seagrass presence depends on the nature of the sediment, where (Hla) hotspot sediments have finer sediments than sediments with infrequent seagrass presence (coldspots), and ( $\mathrm{Hlb}$ ) hotspot seagrass cover increases with decreasing grain size and lack of disturbances (that is, bioturbation).

H2 Actual seagrass cover of hotspots is negatively affected by winter sediment processes, rather than summer sediment processes.

Furthermore, we expect the presence of a critical threshold value of the maximum sediment disturbance depth for actual seagrass presence, above which seagrass presence is affected by sediment disturbances (leading to uprooting). As maximum sediment disturbance depth is the result of several sediment characteristics and processes, the relationship between these characteristics and the maximum sediment disturbance depth is investigated as well.

\section{Methods and Materials}

\section{Sample Point Selection}

Seven intertidal $Z$. noltii seagrass meadows with more than 20 years of seagrass presence were selected across the Eastern Scheldt tidal basin (Figure $1 \mathrm{~A}, \mathrm{~B})$. These seagrass meadows were mapped by Rijkswaterstaat (part of the Dutch Ministry of Infrastructure and the Environment) every second year. The meadows were still present in the year prior to the measurements (2011). We identified the so-called seagrass "hotspots"; areas within a meadow where seagrass was found during all mapping campaigns and that thus seem to have the best conditions for seagrass growth (Figure 1C-I, in black). Recently, 4 out of the 7 selected meadows suffered a significant decline in seagrass cover and area, with only sparse seagrass cover remaining in seagrass hotspots. We therefore distinguished hotspots with either dense or sparse seagrass cover. We also identified seagrass "coldspots": areas with infrequent seagrass presence during 1989-1998 (presence only $30-40 \%$ of the years monitored), and absence during 1999-2009. Coldspots lie within the range of colonization by vegetative growth or seedfall, but are probably not (or only very marginally) suited for seagrass growth (Figure 1C-I, in white). Sampling points were selected within the hotspots (3 replicates per hotspot, white bullets) and coldspots (4-6 replicates per coldspot, black bullets). The meadows' air exposure time ranged from 50 to $70 \%$ of the tidal cycle; tidal amplitude was $3 \mathrm{~m}$. Exposure to hydrodynamics for each meadow was assessed by a 2D wave and current velocity model by Rijkswaterstaat, Ministry of Infrastructure and Environment. The Eastern Scheldt is a relatively sheltered system with a reduced tidal movement, little wind fetch, and small waves compared to coastal systems (Louters and others 1998). Temperature does not differ much between meadows in the Eastern Scheldt (Govers unpublished results). Suspended sediment concentrations are very low throughout the Eastern Scheldt (data Ministry of Infrastructure and Environment).

\section{Monitoring}

To assess how seagrass presence correlated with several sediment properties, we measured static sediment properties and seagrass presence in the summer of 2012, and we measured dynamic sediment properties from April 2012 up until May 2013, with an interval of approximately 7-9 weeks. At the beginning of the summer of 2012, static sediment characteristics were measured by taking $20 \mathrm{ml}$ sediment cores from the top $5 \mathrm{~cm}$ that were further processed (wet weighted, freeze-dried, dry weighted, sieved over $1 \mathrm{~mm}$ ) prior to grain size distribution analysis by laser diffraction on a particle sizer (Malvern, Worchester, UK) and dry bulk density calculation equation 1 .

Sediment bulk density ${ }_{\text {dry }}=\frac{\text { Dry weight }(\mathrm{gr})}{\text { Total volume }\left(\mathrm{cm}^{3}\right)}$.

At the same time, the elevation (Amsterdam Ordnance Datum) of each sampling point was measured using a real-time kinetic differential GPS (RTK-dGPS, Leica Viva GS12 GNSS receiver and CS15 controller), with a vertical accuracy of less than $2 \mathrm{~mm}$. To separate the effects of seasons and aboveground seagrass biomass, data were pooled 

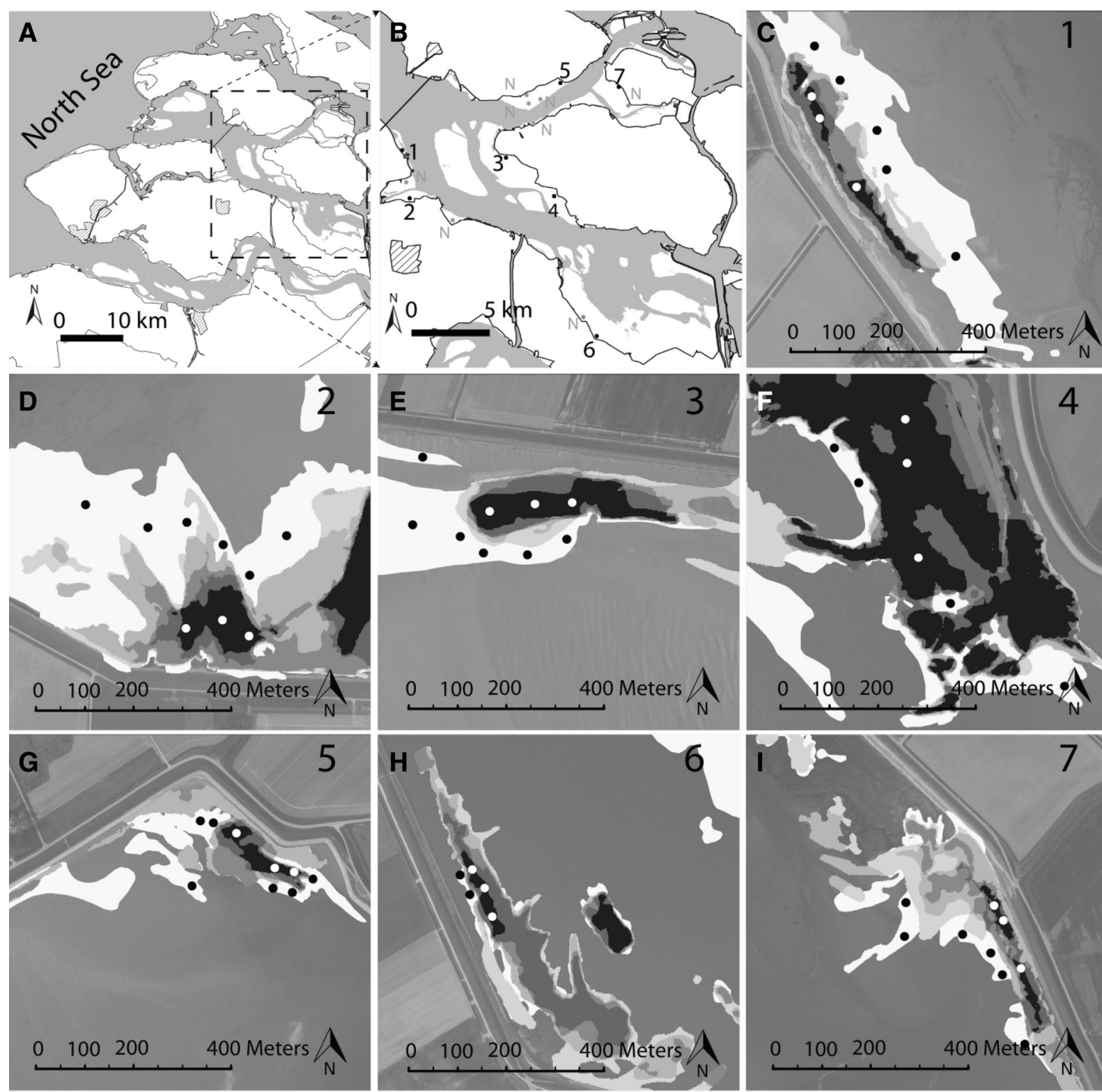

\section{Seagrass presence:} 1989 ------> 1998 1999 2009 infrequent presence \begin{tabular}{l|l|l|lll}
$1-20$ & $21-40$ & $41-60$ & $61-80$ & $81-100$ & $\%$ of years
\end{tabular}

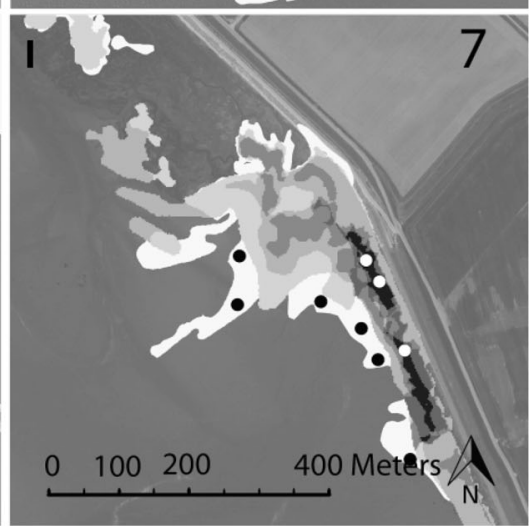

\section{Sampling points:}

- Seagrass coldspot

Seagrass hotspot

Figure 1. A, B Location of the monitored seagrass meadows across the Eastern Scheldt tidal basin, SW Netherlands (numbers indicate the selected meadows, " $N$ " all other). CI seagrass presence maps for each selected meadow (top right numbers correspond with numbers in $\mathbf{B}$ ). Grayscale colors represent the percentage of years that area had greater than $5 \%$ coverage at mapping surveys during

per season: summer (growing season, AprilNovember 2012 and March-May 2013) and winter (non-growing season, November 2012-March
1999-2009 (data Rijkswaterstaat). Black areas are considered as seagrass hotspots (areas within a meadow where seagrass was found during all mapping campaigns). White areas are considered as seagrass coldspots (areas with infrequent seagrass presence during 1989-1998, and absence during 1999-2009). Sampling points of coldspot and hotspot areas are indicated by white and black bullets, respectively.

2013). To assess sediment dynamics, first, bed level change was measured as the vertical height difference between initial bed level (marked on 2 sepa- 
rate bamboo sticks per sampling point) and the bed level at the time of measurement. For analysis, bed level changes were pooled per sampling point. Secondly, we measured till what depth the sediment was disturbed or did move during our sampling interval by using fluorescent dyed sediment tracer rods (Runte 1989). Universal rods were used for all locations, consisting of a 17:1 volume ratio mix of moist sediment from the Tholseinde tidal flat (median grain size: $D_{50} \sim 100 \mu \mathrm{m}$ ) and dry inert, fluorescent tracer (luminophores, $D_{50}=41 \mu \mathrm{m}$; Environmental Tracing Systems, UK; http://www. environmentaltracing.com). The prepared, frozen tracer rods $(10 \mathrm{~cm}$ long $\times 1.5 \mathrm{~cm}$ diameter $)$ were vertically positioned in the sediment in a pilot hole and leveled with the surrounding bed level. At the next sampling visit, the (remaining) rod was retrieved by taking a large core $(30 \mathrm{~cm}$ depth $\times 4.0 \mathrm{~cm}$ diameter) using a template, and cores were kept upright until being frozen at the institute. Frozen cores were cut lengthwise to measure (under black light) the depth of the bottom of the tracer rod, its remaining length, and the depth of the top of the remaining rod (Supplemental Figure 1). The maximum sediment disturbance depth was then calculated from the bed level change and the depth of the top of the remaining tracer rod (equations 2 and 3).

In case of sedimentation:

$$
\begin{aligned}
& \text { Sediment disturbance depth }{ }_{\max } \\
& =\text { Tracer rod depth. }
\end{aligned}
$$

In case of erosion:

$$
\begin{aligned}
& \text { Sediment disturbance depth }{ }_{\max } \\
& \quad=[\text { Bed level change }]+\text { Tracer rod depth. }
\end{aligned}
$$

At each monitoring visit, seagrass presence and cover were recorded as well as adult lugworm densities and their induced pit and mound relief. For analysis in relation to seagrass cover, we used the maximum seagrass cover that was recorded during summer.

\section{Statistical Analyses}

A comparison of sediments from the coldspot- and sparsely vegetated hotspot categories was used to reveal differences between seagrass-suitable and non-suitable sediments without any potential ecosystem engineering effects of seagrass ( $\mathrm{Hla})$. The comparison of sparsely and densely vegetated hotspots was used to test what characteristics are most correlated to seagrass cover. Both comparisons were tested separately using One-Way AN-
OVAs in Sigmaplot v12.0 (Systat Software Inc.). The data were analyzed with ANOVA on ranks if normalized data could not be obtained after data transformation. Results are graphically shown as Tukey boxplots, unless differently stated. The boundary of the box closest to zero indicates the 25th percentile, the line within the box marks the median, and the boundary of the box farthest from zero indicates the 75 th percentile. Whiskers above and below the box indicate the 90th and 10th percentiles. All outliers are represented by dots. Prior to statistical analysis, data were checked for normality and if necessary transformed. To find the relative importance of the effect of each parameter on seagrass cover and on maximum sediment disturbance depth in winter ( $\mathrm{Hlb}$ and $\mathrm{H} 2)$, first Pearson's product-moment correlation coefficients were calculated and statistically tested using R 2.15, and second, a backward stepwise multiple regression analysis was performed in R. For the latter, the final adjusted models were the most reduced models, which were not significantly worse $(P<0.05)$ than the full model that included all factors. Model selection was based on the Akaike Information Criterion (AICs). Models were checked for independence of errors and multi-collinearity.

\section{RESUlts}

The seven selected seagrass meadows showed two distinct levels of vegetation cover in the year of our study. Three hotspots had high seagrass cover in summer $(>30 \%)$, whereas four hotspots had sparse cover $(2-15 \%)$. In coldspots, seagrass cover was between 0 and $3 \%$, except for a recently expanding meadow showing a cover of $30 \%$ (Supplementary data).

\section{Comparing Coldspots and Sparse Vegetated Hotspots}

To find differences between coldspots and hotspots irrespective of seagrass cover (thus without relevant potential ecosystem engineering effects of seagrass), we compared the coldspots with the four sparsely vegetated hotspots for all measured sediment and meadow characteristics. Sparsely vegetated hotspots had smaller median grain size, lower sediment bulk density, and a higher silt content than seagrass coldspots (Figure 2A-C; Table 2). Elevation did not consistently differ between seagrass hotspots and coldspots (Figure 2D; Table 2). Measures related to sediment dynamics (maximum sediment disturbance depth, lugworm density, and lugworm relief) did not differ between coldspots 

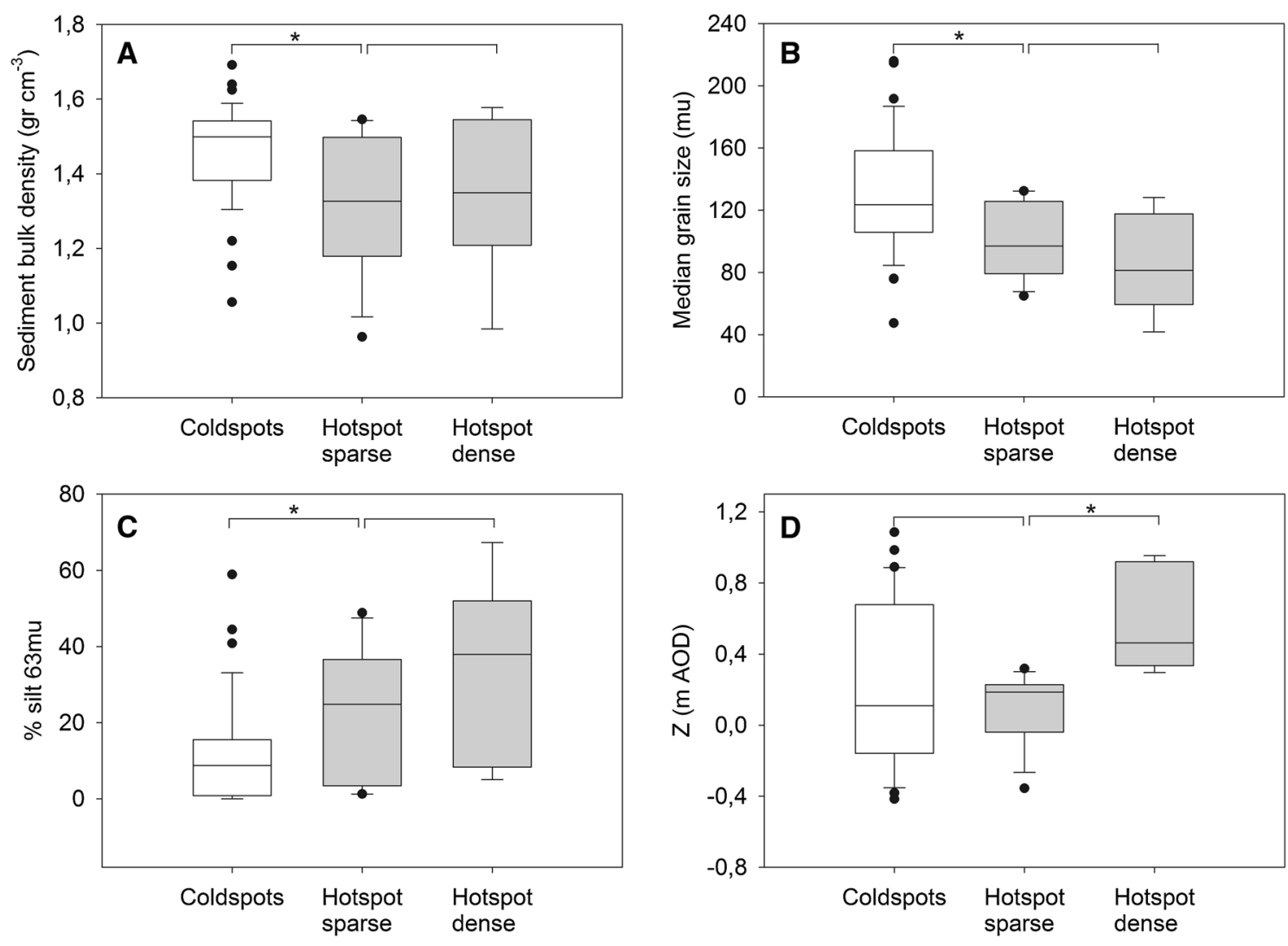

Figure 2. Static sediment characteristics and absolute elevation of sampling points in natural meadows, split into 3 seagrass categories, namely coldspots (historical, but no recent seagrass cover), hotspot_low (recent, low seagrass

and sparsely vegetated hotspots, in winter or summer (Figure 3; Table 2).

\section{Comparing Sparsely and Densely Vegetated Hotspots}

To gain insight into whether characteristics of hotspots that distinctly differ in actual seagrass cover are structurally different, we compared sparsely vegetated hotspots $(2-15 \%$ cover $)$ with densely vegetated hotspots ( $>30 \%$ cover). Static sediment characteristics, that is, median grain size, sediment bulk density, and silt content, did not differ between the two types of hotspot (Figure 2AC; Table 2). Densely vegetated hotspots were found at an elevation that was around $60 \mathrm{~cm}$ higher than that of sparsely vegetated hotspots. As general hydrodynamic exposure of the meadows was similar (Table 1, unpaired $T$ test $P>0.1$ ), the higher elevated beds experienced hydrodynamics during shorter periods, thus contributing to lower sediment dynamics (that is, van Katwijk and Hermus 2000). The maximum disturbance depth was lower

cover), and hotspot_high (recent, high seagrass cover). Significant differences between the seagrass categories (one-way ANOVA, significance level: $P<0.05$ ) are indicated with asterisk.

at densely vegetated hotspots compared to sparsely vegetated hotspots, both in summer (14 vs. $29 \mathrm{~mm}$ ) and in winter (19 vs. $32 \mathrm{~mm}$ ) (Figure 3A, $\mathrm{B}$; Table 3). Densely vegetated hotspots had lower lugworm densities and relief in winter compared to sparsely vegetated hotspots, whereas in summer, lugworm densities and relief were comparable (Figure 3C-F; Table 4). Bed level change did not differ significantly between sparse and dense hotspots at any moment in time (Table 3 ).

\section{Explaining Seagrass Cover by Sediment Characteristics}

To assess what parameter explains seagrass cover best, we used multiple backward stepwise regressions, using all static, dynamic, and faunal sediment variables. This showed that maximum seagrass cover is best (62\%) explained by a model containing maximum sediment disturbances in winter, lugworm relief in winter, and median grain size (Table 5). Note that lugworm winter density was strongly correlated with lugworm winter relief 

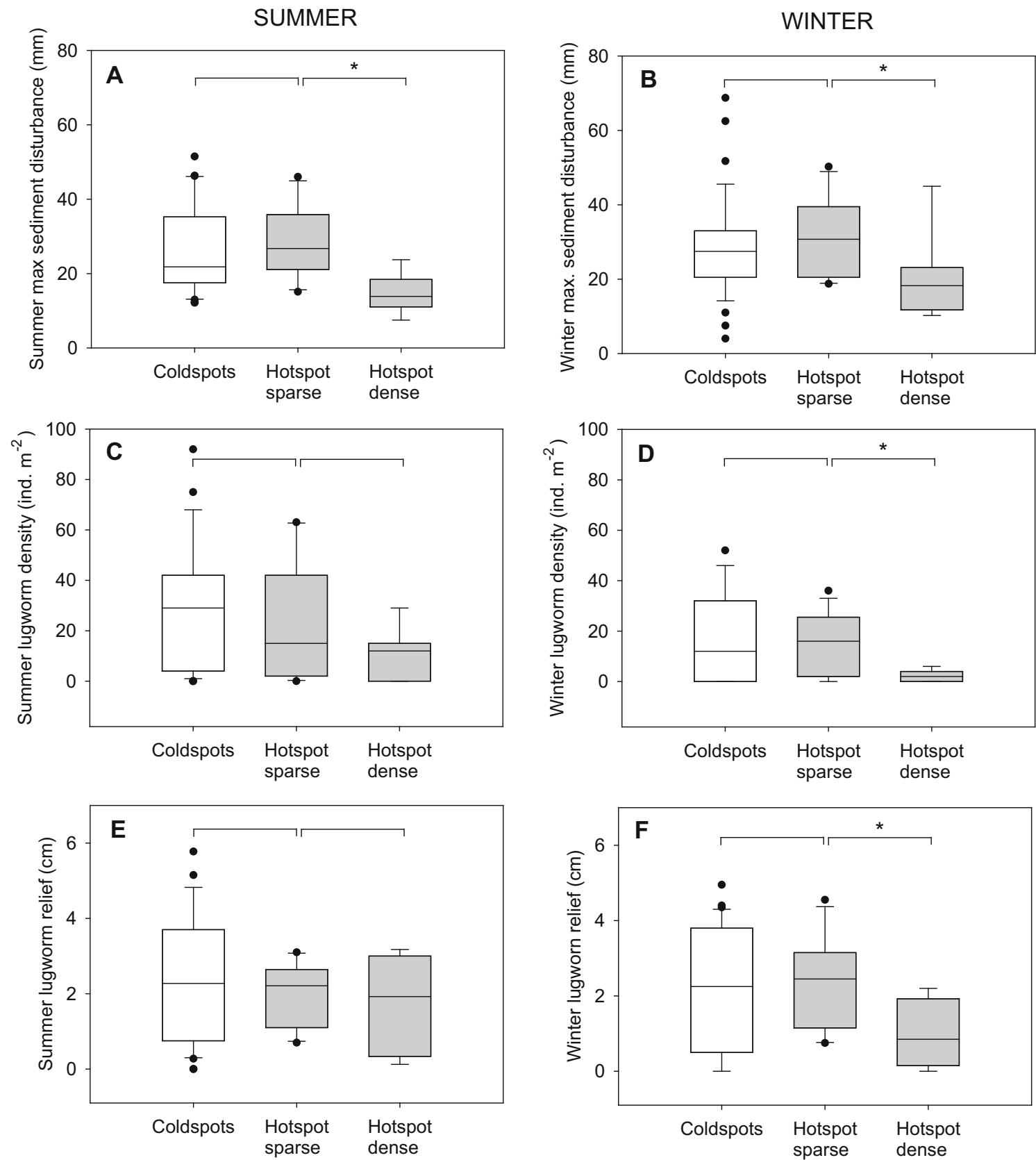

Figure 3. Maximum sediment disturbance, lugworm densities, and lugworm relief, split into summer (left panels) and winter (right panels). Significant differences between

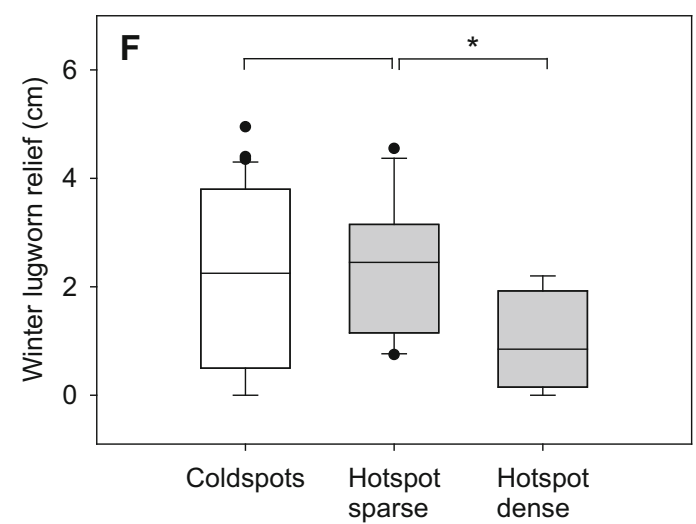

the seagrass categories (one-way ANOVA, significance level: $P<0.05)$ are indicated with asterisk.

$(r=0.78)$ and was therefore deleted from the regression analysis to meet collinearity rules. Seagrass cover also correlates with elevation $(r=0.39$, $P<0.05$, Table 4 ), but this does not significantly enhance the explanation by the model.

Plotting the significantly correlated maximum disturbance depth and the maximum seagrass cover against each other revealed a clear critical disturbance threshold both in summer and winter (Figure 4). Disturbance depths of more than

$25 \mathrm{~mm}$ almost always coincided with sparsely vegetated hotspots, whereas hotspots with disturbance depths below that "critical" threshold can be dense as well as sparse.

\section{Explaining Maximum Sediment Disturbance Depth}

As maximum sediment disturbance is a parameter integrating several environmental characteristics 
Table 1. Current Velocity $\left(\mathrm{cm} \mathrm{s}^{-1}\right)$ and Significant Wave Height $(\mathrm{cm})$ of the Seven Hotspots

\begin{tabular}{llll}
\hline Hotspot category & Hotspot no. & Current velocity $\left(\mathrm{cm} \mathrm{s}^{-1}\right)$ & Significant wave height $(\mathrm{cm})$ \\
\hline Dense & 3 & 18.3 & 16.0 \\
Dense & 6 & 22.8 & 19.4 \\
Dense & 7 & 17.5 & 15.0 \\
Sparse & 1 & 25.1 & 44.6 \\
Sparse & 2 & 16.7 & 26.6 \\
Sparse & 4 & 14.6 & 21.3 \\
Sparse & 5 & 11.1 & 11.0
\end{tabular}

Data derived from SCAROOST 2D model from Rijkswaterstaat, Dutch Ministry of Infrastructure and Environment. The model uses the systems bathymetry (2010 data) and is validated by field measurements. Current velocity is the maximum current velocity at spring tide. Significant wave height is the wave height under stormy conditions. The tidal range in our study area varies between 2.4 and $3.5 \mathrm{~m}$, maximum current velocities range from up to $0.3 \mathrm{~m} \mathrm{~s}^{-1}$ in the shallow areas to $1-1.5 \mathrm{~m} \mathrm{~s}^{-1}$ in the tidal channels, and waves are generated within the system by wind (Louters and others 1998).

Table 2. One-Way ANOVA Significance Test Outcomes of the Comparison of Seagrass Coldspots with Sparsely Vegetated Hotspots for Sediment and Lugworm Characteristics

\begin{tabular}{|c|c|c|}
\hline \multirow[t]{2}{*}{ Variables } & \multicolumn{2}{|c|}{ Coldspot vs Hotspot_sparse } \\
\hline & $P$ & Sign. \\
\hline Absolute elevation (m AOD ${ }^{1}$ ) & $0.764^{2}$ & \\
\hline Median grain size $(\mathrm{mu})$ & 0.017 & * \\
\hline Dry bulk density (gr $\mathrm{cm}^{-3}$ ) & $0.022^{2}$ & * \\
\hline$\%$ Silt $<63 \mathrm{mu}$ & $0.029^{2}$ & * \\
\hline Bed level change $_{\text {summer }}(\mathrm{mm})$ & $0.920^{2}$ & \\
\hline Bed level change $_{\text {winter }}(\mathrm{mm})$ & $0.450^{2}$ & \\
\hline Max. sediment disturbance summer $_{\text {(mm) }}$ & $0.096^{2}$ & \\
\hline Max. sediment disturbance ${ }_{\text {winter }}(\mathrm{mm})$ & $0.280^{2}$ & \\
\hline Lugworm density $_{\text {summer }}\left(\# \mathrm{~m}^{-2}\right)$ & $0.519^{2}$ & \\
\hline Lugworm density winter $\left(\# \mathrm{~m}^{-2}\right)$ & $0.937^{2}$ & \\
\hline Lugworm relief $_{\text {summer }}(\mathrm{cm})$ & $0.781^{2}$ & \\
\hline Lugworm relief $_{\text {winter }}(\mathrm{cm})$ & $0.747^{2}$ & \\
\hline \multicolumn{3}{|c|}{$\begin{array}{l}\text { Sediment and lugworm characteristics and were split into summer (April-November } 2012 \text { and March-May 2013) and winter (November 2012-March 2013) when data were } \\
\text { available. } \\
{ }^{1} \text { Amsterdam Ordnance Datum. } \\
{ }^{2} 1 \text { way Anova on ranks. } \\
{ }^{*} \text { Significance level } P<0.05 \text {. }\end{array}$} \\
\hline
\end{tabular}

(that is, abiotic sediment characteristics, erosion/ sedimentation processes and bioturbation), we performed a multiple backward stepwise regression on this parameter as well. We found that the maximum sediment disturbance depth was best explained by dry bulk density of the ambient sediment and lugworm density in winter (Table 6). Note that during the regression analysis, median grain size (D50) was excluded in the process to further simplify the model without losing strength, followed by excluding "elevation" after a violation of independence with bulk density.

\section{Discussion}

Monitoring seagrass meadows yielded clear evidence for sediment-related feedbacks affecting seagrass survival and provided insights into how these feedbacks work. Twenty years of monitoring by the Dutch Ministry of Infrastructure and the Environment allowed us to distinguish coldspots (where seagrass was almost never present) and hotspots (where seagrass was always present during this monitoring period). In the year of this study, hotspots were either sparsely $(<15 \%$ cover $)$ or densely ( $>30 \%$ cover) vegetated. Sparsely vegetated hotspots had a higher maximum sediment disturbance depth in winter and a higher lugworm winter relief as compared to densely vegetated hotspots. These two factors explain $62 \%$ of the variation in vegetation cover (multiple backward stepwise regression). Obviously, other factors correlate with these factors as well. For in- 
Table 3. One-Way ANOVA Significance Test Outcomes of the Comparison of Seagrass Hotspots of Low (Hotspot_sparse) and High Plant Density (Hotspot_dense) for Sediment and Lugworm Characteristics

\begin{tabular}{|c|c|c|}
\hline \multirow[t]{2}{*}{ Variables } & \multicolumn{2}{|c|}{ Hotspot_sparse vs Hotspot_dense } \\
\hline & $P$ & Sign. \\
\hline Absolute elevation (m AOD ${ }^{1}$ ) & 0.001 & $* *$ \\
\hline Median grain size $(\mathrm{mu})$ & 0.306 & \\
\hline Dry bulk density $\left(\mathrm{gr} \mathrm{cm}^{-3}\right.$ ) & 0.751 & \\
\hline$\%$ Silt $<63 \mathrm{mu}$ & $0.227^{2}$ & \\
\hline Bed level change summer $(\mathrm{mm})$ & 0.175 & \\
\hline Bed level change winter $(\mathrm{mm})$ & 0.152 & \\
\hline Max. sediment disturbance summer $(\mathrm{mm})$ & 0.813 & \\
\hline Max. sediment disturbance ${ }_{\text {winter }}(\mathrm{mm})$ & 0.021 & * \\
\hline Lugworm density summer $\left(\# \mathrm{~m}^{-2}\right)$ & 0.110 & \\
\hline Lugworm density winter $\left(\# \mathrm{~m}^{-2}\right)$ & $0.017^{2}$ & * \\
\hline Lugworm relief $_{\text {summer }}(\mathrm{cm})$ & 0.496 & \\
\hline Lugworm relief $_{\text {winter }}(\mathrm{cm})$ & 0.015 & * \\
\hline \multicolumn{3}{|c|}{$\begin{array}{l}\text { Variables were split into summer (April-November } 2012 \text { and March-May 2013) and winter (November 2012-March 2013) when data were available. } \\
{ }^{2} \text { Amsterdam Ordnance Datum. } \\
{ }^{2} 1 \text { way Anova on ranks. } \\
{ }^{*} \text { Significance level } P<0.05 \text {. } \\
* * \text { Significance level } P<0.01 .\end{array}$} \\
\hline
\end{tabular}

stance, maximum sediment disturbance depth was best explained by dry bulk density of the ambient sediment and lugworm density in winter. Tidal elevation, although not having a prominent role in explaining variation by stepwise regression, in general contributes to sediment stability by affecting (i) the time interval of exposure to hydrodynamics, (ii) sediment compaction, and (iii) potentially (indirectly) the lugworm relief and density.

Building on our results and on the literature, we pose a conceptual model containing a self-sustaining feedback loop for densely vegetated meadows and a runaway feedback loop for sparsely vegetated seagrass meadows (Figure 5).

\section{Self-sustaining Feedback Loop}

Seagrass ecosystem engineering capacities are widely acknowledged and reported; they are related to their canopy, that is, flow and wave reduction, sediment trapping, reduced re-suspension (Bos and van Katwijk 2007), but also related to their belowground biomass, that is, improving sediment stability (Christianen and others 2013) and outcompeting bioturbators (Philippart 1994; Berkenbusch and others 2007; Reise and Kohlus 2008; Eklof and others 2011). A comparison between sparse and dense hotspots showed that sparsely vegetated hotspots $(<15 \%$ cover) have higher sediment dynamics (deeper disturbance depth, more lugworms, and more lugworm relief) than dense hotspots ( $>30 \%$ cover), at comparable static sediment properties (that is, median grain size and bulk density, Figure 3). This implies that densely vegetated hotspots may limit sediment dynamics, which in turn facilitates seagrass (Cabaco and others 2008; Han and others 2012; Suykerbuyk and others 2012), thus establishing a self-sustaining feedback loop (Figure 5).

\section{Runaway Feedback Loop}

With decreasing seagrass densities, the seagrass sediment may be more disturbed (increased lugworm densities and less protection from wave impact) and more susceptible to disturbances (sediments getting more mobile) (that is, Cabaco and others 2008). In our study, sparsely vegetated hotspots, whereas having static sediment characteristics similar to densely vegetated hotspots and a history of high seagrass cover, showed greater sediment dynamics than densely vegetated hotspots; sparsely vegetated hotspot dynamics were in fact comparable to those of coldspots. This may inhibit seagrass recovery, thus establishing a runaway feedback loop (Figure 5). Eventually, this runaway loop might result in total loss of seagrass and its habitat. An accelerated decline may have occurred in the sparsely vegetated hotspots in recent years. Such declines could have been initiated by any large-scale stochastic anthropogenic or climatological disturbance (for example, prolonged storms from unfavorable directions combined with 


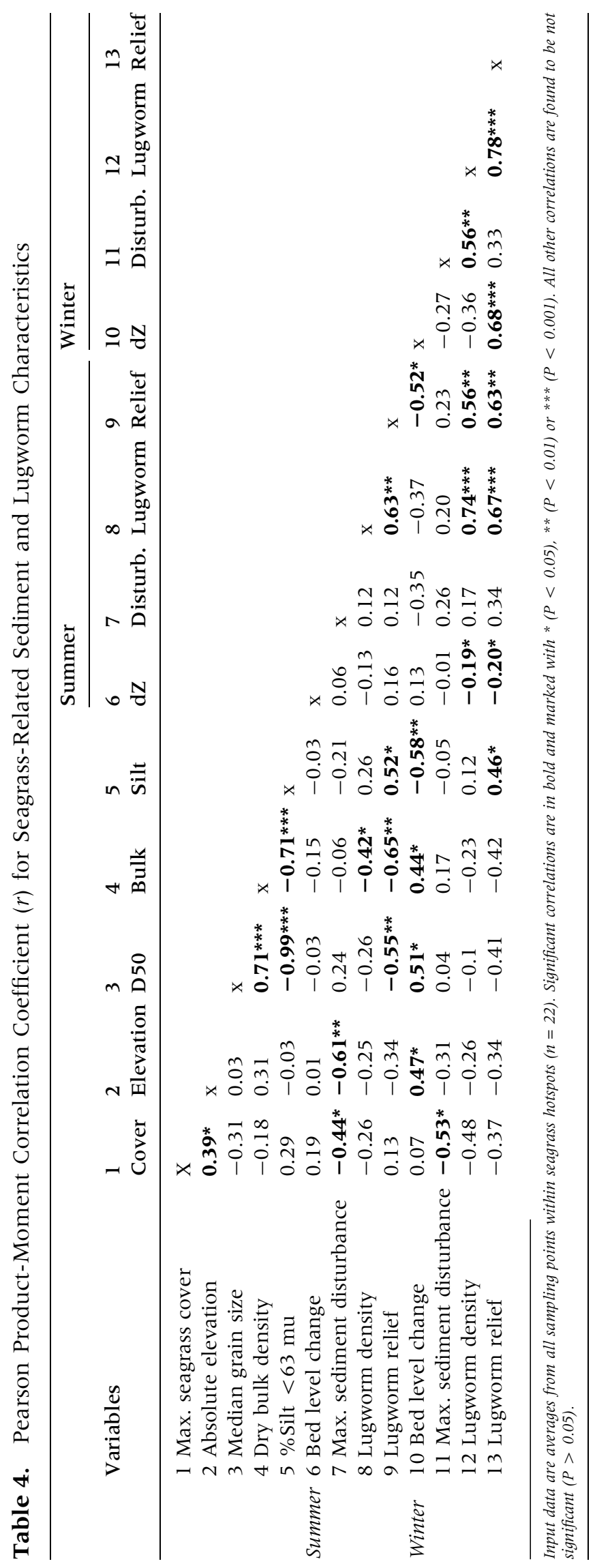


Table 5. Summary of Multiple Backward Stepwise Regression Statistics for the Predictor Variables to Maximum Seagrass Cover

\begin{tabular}{|c|c|c|c|c|c|}
\hline Reduced model & $\Delta R^{2}$ & B & SE B & $P$ & Sign. \\
\hline Adjusted model & 0.62 & 14.31 & 2.27 & $<0.001$ & $* * *$ \\
\hline Max sediment disturbance ${ }_{\text {winter }}$ & & -0.094 & 0.04 & 0.046 & * \\
\hline Median grain size & & -0.067 & 0.01 & 0.008 & $* *$ \\
\hline Lugworm relief $_{\text {winter }}$ & & -1.34 & 4.43 & 0.007 & $* *$ \\
\hline \multicolumn{6}{|c|}{$\begin{array}{l}\Delta R^{2}=\text { fit of the reduced model, } B=\text { unstandardized beta coefficient, SE } B=\text { standard error, } P=\text { significance value, Sign. }=\text { significance level. }(\text { Full model: all variables listed } \\
\text { in the column headings of Table } 4) \text {. } \\
* \text { Significance level } P<0.05 \text {. } \\
* * \text { Significance level } P<0.01 . \\
* * * \text { Significance level } P<0.001 .\end{array}$} \\
\hline
\end{tabular}

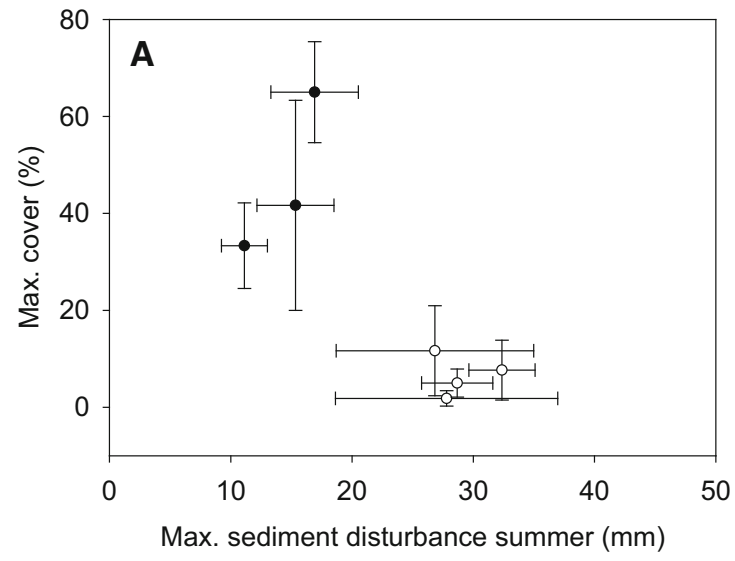

Figure 4. Relation between the maximum sediment disturbance (mm, $x$-axis, summer $\mathbf{A}$, winter $\mathbf{B}$ ) and the maximum seagrass cover in summer ( $\%, y$-axis). Bullets represent hotspot averages per location \pm standard error.

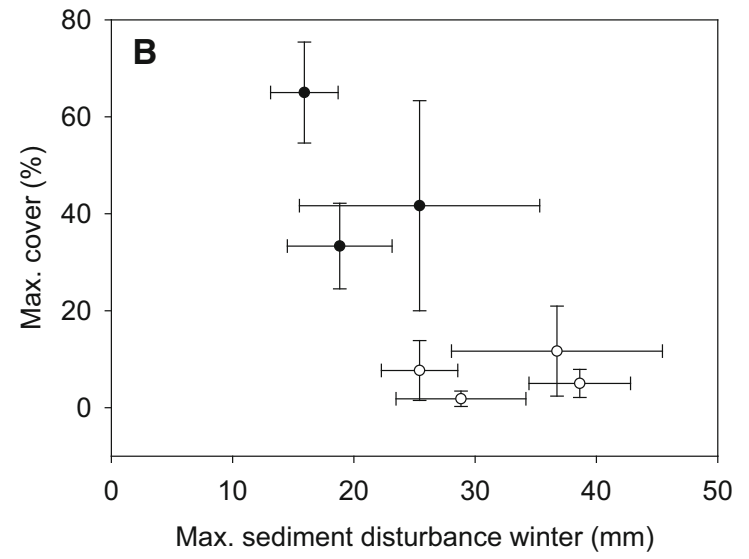

Open symbols represent sparsely vegetated hotspots, filled bullets densely vegetated hotspots. Densely vegetated hotspots are on average found at small maximum winter sediment disturbances (less the $25 \mathrm{~mm}$ ).

Table 6. Summary of Multiple Backward Stepwise Regression Statistics for the Predictor Variables to Maximum Sediment Disturbance ${ }_{\text {winter }}$

\begin{tabular}{|c|c|c|c|c|c|}
\hline Reduced model & $\Delta \mathrm{R}^{2}$ & B & SE B & $\mathbf{P}$ & Sign. \\
\hline Adjusted model & 0.42 & -16.87 & 18.94 & 0.385 & \\
\hline Sqrt Lugworm density ${ }_{\text {winter }}$ & & 3.73 & 1.09 & 0.003 & $* *$ \\
\hline Dry bulk density & & 25.88 & 13.2 & 0.067 & \\
\hline
\end{tabular}

$\Delta R^{2}=$ fit of the reduced model, $B=$ unstandardized beta coefficient, SE B = standard error, $P=$ significance value, Sign. $=$ significance level, Sqrt $=$ square root. $($ Model: All variables listed in the column headings of Table 4 except those of summer).

**Significance level $p<0.01$.

increased water levels, or frequent lugworm digging, or deep ice-scour), thus breaking the selfsustaining feedback related to sediment dynamics. The presence of either low or high cover seagrass beds, as well as the threshold for sediment dynamics, supports the conceptual runaway feedback model depicted in Figure 5.
Whether the seagrass loss is initiated by structural external forcing, by a more stochastic disturbance initiating a runaway loop or a mix of both, long-term presence of low-cover seagrass meadows indicates that the sites have a minimum suitability for seagrass survival. Following our conceptual model, these beds may recover as soon as a window 

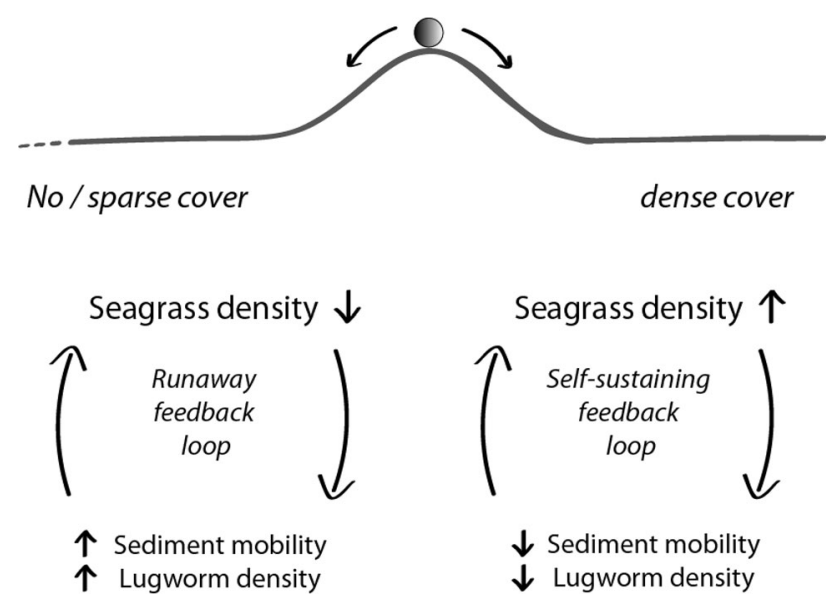

of opportunity allows the beds to reach $33 \%$ cover or more. Such a window of opportunity should consist of a prolonged period of low sediment dynamics. Alternatively, when the seagrass loss is the result of permanent local changes, such as higher or more frequent sediment disturbances (Nienhuis and others 1994; ten Brinke and others 1994), only a permanent solution, that is, a manmade structure that reduces the excess of disturbances, could help to recover the seagrass beds.

\section{Seasonality as Bottleneck for Seagrass Survival in Temperate Climates}

In general, winter rather than summer processes were found to be most important for summer seagrass cover in the stepwise multiple backward regression. During winter, seagrass is at the mercy of generally more extreme and varying environmental conditions (that is, storms and ice events). Moreover, during summer, seagrass is able to quickly react to dynamic environmental processes, like burial and erosion (Cabaco and others 2008; Han and others 2012). In winter, growth is minimal, and aboveground seagrass biomass is largely lost. Only rhizomes with winter reserves and some apical shoots remain (Vermaat and Verhagen 1996); these shoots do not contribute to the winter reserves (Govers and others 2015). The relationship between seagrass cover and winter processes may imply a dominant engineering role of the belowground biomass. Our study shows that highest seagrass winter survival and thus highest potential summer seagrass cover are likely to be found at spots that have stable sediments. Such spots are either sheltered from winter storms and therefore experience less wave-induced sediment mixing, or are located at higher elevations where exposure to hydrodynamics is interrupted by period of low tide for a longer period, or lack bioturbating animals, or
Figure 5. A conceptual diagram showing the bimodal seagrass density distribution that was found in the Eastern Scheldt tidal basin (above). The posed positive feedback loops from which the density distribution derives (below). have shell-rich, packed and cohesive sediments that are less prone to disturbances, or a combination of those, which often occurs (correlation matrix see Table 4). The importance of stable sediments was already suggested by Reise and Kohlus (2008) for the highly dynamic temperate Northern Wadden Sea. Here, we show that this relationship also applies in relatively sheltered delta systems with a reduced tidal movement, little wind fetch, and small waves compared to coastal systems.

\section{Maximum Sediment Disturbance Depth}

The maximum sediment disturbance depth is strongly correlated to seagrass cover and is very distinct between the sparsely and densely vegetated hotspots, showing a threshold at around $25 \mathrm{~mm}$. The observed maximum disturbance depth itself is best explained by bulk density of the ambient hotspot sediment and lugworm density in winter (Table 6), and thus integrates both the nature of sediment and its disturbances. The maximum disturbance depth could therefore be a useful indicator for the restoration and long-term survival potential of species that require low sediment dynamics like the shallow-rooted Z. noltii, but also for other benthic species, such as mangroves and bivalves (that is, Bouma and others 2001; Balke and others 2013a). In general, the maximum sediment disturbance depth could well preclude the persistence of organisms below a certain size and may influence the trade-off between investments in belowground (anchoring) parts versus aboveground parts. For settlement, anchoring has to occur within a certain window of opportunity during which sediment levels remain constant (compare Balke and others 2011, 2014). More specifically, as sediments will be continuously reworked, the anchoring 'rate' should exceed the sediment-re- 
working rate. At this moment, the maximum sediment disturbance depth is rarely quantified. Further research on the maximum sediment disturbance depth may help to explain species compositions of communities, and recruitment traits, size distributions, and morphology of organisms in estuarine and coastal environments.

\section{An Optimal Seagrass Habitat in the Eastern Scheldt: Sediment Dynamics Versus Desiccation Stress}

In our study area, the Eastern Scheldt, high potential Z. noltii habitats were shown to have low sediment dynamics and low lugworm numbers. Low sediment dynamics are correlated to a low sediment bulk density (in addition to occurring on locations that are sheltered from winter storms and have small fetches for wave buildup). In our system and most likely in other intertidal systems, such sediments are generally found in the upper intertidal zone. Here, bulk density is lower as a result of settlement or retention of fine sediments due to (i) longer emersion periods, (ii) shorter durations of exposure to hydrodynamics, and (iii) extensive emergence periods ( $>6 \mathrm{~h}$ per $12 \mathrm{~h}$ tidal period) that largely exclude adult lugworm presence and their bioturbation. For this reason, long-term seagrass persistence is expected in these upper intertidal zones, which is actually what we found (Figure 3D). However, every day, growing conditions for seagrass in this zones are sub-optimal due to desiccation stress (that is, Boese and others 2005; Shafer and others 2007; van der Heide and others 2010; Suykerbuyk and others, submitted).

\section{Future Perspective of Hotspots}

With ongoing climate change, it is expected that environmental extremes like large winter storms will increase in strength and/or occur more frequently (Harley and others 2006; Björk and others 2008). As a direct result, sediment dynamics may be expected to increase in size and frequency (that is, alternating erosion and deposition events). For seagrass that is naturally sheltered from winter abiotic disturbances or that inhabits sediments that are non-susceptible to sediment dynamics (that is, shell banks or extremely cohesive sediments with low bulk density), this might not have any adverse effects. However, for seagrass living under sub-optimal conditions, this may lead to declines, as rhizomal (winter) survival will become limited. Recruitment from seeds may then become more important for meadow resilience and persistence
(Zipperle and others 2009). When beds have disappeared, seed availability may become an important bottleneck (Orth and others 2006b). Provided seeds are available, seedling development will simultaneously decrease with increasing sediment dynamics (that is, Infantes and others 2011; Balke and others 2013b, 2014). In addition, antagonistic ecosystem engineers like lugworms may benefit from enhanced sediment dynamics (van Wesenbeeck and others 2007; Suykerbuyk and others 2012).

Besides direct effects, climate change will also indirectly affect seagrass persistence. Sea level rise and increased weather extremes will call for ongoing coastal constructions that protect us and our economic activities against flooding (Temmerman and others 2013). Following such 'hard' constructions, seascapes will change, often resulting in temporarily or permanently increased sediment dynamics. As our study shows, this may threaten seagrass persistence. Installing ecosystem-based flood defenses by ecosystem creation and restoration of ecosystem engineering species such as shellfish beds and saltmarshes, and eventually seagrasses may prove to be more sustainable and cost-effective (Borsje and others 2011; Temmerman and others 2013). Our study provides valuable insights in the boundary conditions that are needed to ensure long-term persistence of high-density seagrass meadows, along with their ecosystem and coastal protection services.

Summarizing, from this correlative study, we conclude that long-term temperate, intertidal $Z$. noltii presence is restricted by winter sediment dynamics. Densely vegetated hotspots were shown to have lower sediment dynamics than sparsely vegetated hotspots and coldspots, whereas static sediment characteristics (grain size, bulk density) were similar across the different spots. The vegetation cover was either low $(2-15 \%)$ or high $(>30 \%)$, and sediment dynamics showed a threshold for vegetation cover. From this correlative finding, we postulate a self-sustaining feedback of relatively dense seagrass via sediment stabilization, and accordingly, a runaway feedback once the seagrass cover becomes too sparse. Recovery after losses requires a window of opportunity that can be stochastic, or can be created by temporal or permanent habitat measures (that is creating sediment stabilization). The sensitivity for sediment dynamics shown in our study implies that future existence of seagrass meadows may be at risk as ongoing climate change might directly (increased environmental extremes) or indirectly (changing seascapes) negatively affect seagrass beds. However, 
increased insights in the bottlenecks for long-term seagrass survival also open opportunities for setting the boundaries to create successful seagrass restoration projects. So, perhaps in the end, Nietzsche's saying "That which does not kill us, makes us stronger," counts for both seagrasses and the scientists studying them.

\section{ACKNOWLEDGEMENTS}

We gratefully acknowledge Rijkswaterstaat for providing the long-term seagrass maps and Annette Wielemaker for GIS processing of these maps. Furthermore, special thanks is given to Laura Glasbergen and Thera Heslenfeld for optimizing the fluorescent tracer method, Wim Giesen for feedback on the monitoring set-up and its analysis, Roy van der Voort for his administrative efforts that ensured legal access to all field sites, and Steef Hanssen for editing the English language.

\section{OPEN ACCESS}

This article is distributed under the terms of the Creative Commons Attribution 4.0 International License (http://creativecommons.org/licenses/by/ 4.0/), which permits unrestricted use, distribution, and reproduction in any medium, provided you give appropriate credit to the original author(s) and the source, provide a link to the Creative Commons license, and indicate if changes were made.

\section{REFERENCES}

Balke T, Bouma TJ, Herman PMJ, Horstman EM, Sudtongkong C, Webb EL. 2013a. Cross-shore gradients of physical disturbance in mangroves: implications for seedling establishment. Biogeosciences 10:5411-19.

Balke T, Bouma TJ, Horstman EM, Webb EL, Erftemeijer PLA, Herman PMJ. 2011. Windows of opportunity: thresholds to mangrove seedling establishment on tidal flats. Mar Ecol Prog Ser 440:1-9.

Balke T, Herman PMJ, Bouma TJ. 2014. Critical transitions in disturbance-driven ecosystems: identifying windows of opportunity for recovery. J Ecol 102:700-8.

Balke T, Webb EL, van den Elzen E, Galli D, Herman PMJ, Bouma TJ. 2013b. Seedling establishment in a dynamic sedimentary environment: a conceptual framework using mangroves. J Appl Ecol 50:740-7.

Bastyan GR, Cambridge ML. 2008. Transplantation as a method for restoring the seagrass Posidonia australis. Estuar Coast Shelf Sci 79:289-99.

Berkenbusch K, Rowden AA, Myers TE. 2007. Interactions between seagrasses and burrowing ghost shrimps and their influence on infaunal assemblages. J Exp Mar Biol Ecol 341:70-84.

Björk M, Short F, Mcleod E, Beer S. 2008. Managing seagrasses for resilience to climate change. Switzerland: IUCN Gland. p 56.
Boese BL, Robbins BD, Thursby G. 2005. Desiccation is a limiting factor for eelgrass (Zostera marina L.) distribution in the intertidal zone of a northeastern Pacific (USA) estuary. Bot Mar 48:274-83.

Borsje BW, van Wesenbeeck BK, Dekker F, Paalvast P, Bouma TJ, van Katwijk MM, de Vries MB. 2011. How ecological engineering can serve in coastal protection. Ecol Eng 37:11322.

Bos AR, van Katwijk MM. 2007. Planting density, hydrodynamic exposure and mussel beds affect survival of transplanted intertidal eelgrass. Mar Ecol Prog Ser 336:121-9.

Bouma H, Duiker JMC, de Vries PP, Herman PMJ, Wolff WJ. 2001. Spatial pattern of early recruitment of Macoma balthica (L.) and Cerastoderma edule (L.) in relation to sediment dynamics on a highly dynamic intertidal sandflat. J Sea Res 45:79-93.

Cabaco S, Santos R, Duarte CM. 2008. The impact of sediment burial and erosion on seagrasses: a review. Estuar Coast Shelf Sci 79:354-66.

Cadée GC. 1976. Sediment reworking by Arenicola marina on tidal Xats in the Dutch Wadden Sea. Netherlands J Sea Res 10:440-60.

Campbell ML, Paling EI. 2003. Evaluating vegetative transplant success in Posidonia australis: a field trial with habitat enhancement. Mar Pollut Bull 46:828-34.

Christianen MJA, van Belzen J, Herman PMJ, van Katwijk MM, Lamers LPM, van Leent PJM, Bouma TJ. 2013. Low-canopy seagrass beds still provide important coastal protection services. Plos One 8:e62413.

Coosen J, Seys J, Meire PM, Craeymeersch J. 1994. Effect of sedimentological and hydrodynamical changes in the intertidal areas of the Oosterschelde estuary (SW Netherlands) on distribution, density and biomass of some common macrobenthic species. Hydrobiologia 282/283:235-49.

Davis RC, Short FT. 1997. Restoring eelgrass, Zostera marina L., habitat using a new transplanting technique: the horizontal rhizome method. Aquat Bot 59:1-15.

Eklof JS, van der Heide T, Donadi S, van der Zee EM, O'Hara R, Eriksson BK. 2011. Habitat-mediated facilitation and counteracting ecosystem engineering interactively influence ecosystem responses to disturbance. Plos One 6:e23229.

Fonseca MS, Bell SS. 1998. Influence of physical setting on seagrass landscapes near Beaufort, North Carolina, USA. Mar Ecol Prog Ser 171:109-21.

Fonseca MS, Kenworthy WJ. 1987. Effects of current on photosynthesis and distribution of seagrasses. Aquat Bot 27:5978.

Fonseca MS, Kenworthy WT, Courtney FX, Hall MO. 1995. Seagrass planting in the Southeastern United-States-methods for accelerating habitat development. Restor Ecol 3:70.

Gambi MC, Nowell ARM, Jumars PA. 1990. Flume observations on flow dynamics in Zostera-marina (eelgrass) beds. Mar Ecol Prog Ser 61:159-69.

Govers LL, Suykerbuyk W, Hoppenreijs J, Giesen K, Bouma TJ, Katwijk MM. 2015. Rhizome starch as indicator for temperate seagrass winter survival. Ecol Indic 49:53-60.

Hammerstrom K, Sheridan P, McMahan G. 1998. Potential for seagrass restoration in Galveston Bay, Texas. Texas J Sci 50:35-50

Han QY, Bouma TJ, Brun FG, Suykerbuyk W, van Katwijk MM. 2012. Resilience of Zostera noltii to burial or erosion disturbances. Mar Ecol Prog Ser 449:133-43. 
Harley CDG, Hughes AR, Hultgren KM, Miner BG, Sorte CJB, Thornber CS, Rodriguez LF, Tomanek L, Williams SL. 2006. The impacts of climate change in coastal marine systems. Ecol Lett 9:228-41.

Hughes RG, Lloyd D, Ball L, Emson D. 2000. The effects of the polychaete Nereis diversicolor on the distribution and transplanting success of Zostera noltii. Helgol Mar Res 54:129-36.

Infantes E, Orfila A, Bouma TJ, Simarro G, Terrados J. 2011. Posidonia oceanica and Cymodocea nodosa seedling tolerance to wave exposure. Limnol Oceanogr 56:2223-32.

Irving AD, Tanner JE, Seddon S, Miller D, Collings GJ, Wear RJ, Hoare SL, Theil MJ. 2010. Testing alternate ecological approaches to seagrass rehabilitation: links to life-history traits. J Appl Ecol 47:1119-27.

Lewis RR, Marshall MJ, Bloom SA, Hodgson AB, Flynn LL. 2006. Evaluation of the success of seagrass mitigation at Port Manatee, Tampa Bay, Florida. Valrico: Lewis Environmental Services.

Lotze HK, Lenihan HS, Bourque BJ, Bradbury RH, Cooke RG, Kay MC, Kidwell SM, Kirby MX, Peterson CH, Jackson JBC. 2006. Depletion, degradation, and recovery potential of estuaries and coastal seas. Science 312:1806-9.

Louters T, van den Berg JH, Mulder JPM. 1998. Geomorphological changes of the Oosterschelde tidal system during and after the implementation of the delta project. J Coast Res 14:1134-51.

Nienhuis PH, Smaal AC, Knoester M. 1994. The Oosterschelde estuary-an evaluation of changes at the ecosystem-level induced by civil-engineering works. Hydrobiologia 283:575-92.

Orth RJ, Carruthers TJB, Dennison WC, Duarte CM, Fourqurean JW, Heck KL, Hughes AR, Kendrick GA, Kenworthy WJ, Olyarnik S, Short FT, Waycott M, Williams SL. 2006a. A global crisis for seagrass ecosystems. Bioscience 56:987-96.

Orth RJ, Luckenbach ML, Marion SR, Moore KA, Wilcox DJ. 2006b. Seagrass recovery in the Delmarva Coastal Bays, USA. Aquat Bot 84:26-36.

Philippart CJM. 1994. Interactions between Arenicola-marina and Zostera-noltii on a tidal flat in the Wadden Sea. Mar Ecol Prog Ser 111:251-7.

Reise K, Kohlus J. 2008. Seagrass recovery in the Northern Wadden Sea? Helgol Mar Res 62:77-84.

Reise K. 1985. Tidal flat ecology. Berlin: Springer. p 191.

Runte KH. 1989. Methodische verfahren zur quantifizierung von umlagerungen in intertidalen sedimenten. Meyniana 41:153-65.

Shafer DJ, Sherman TD, Wyllie-Echeverria S. 2007. Do desiccation tolerances control the vertical distribution of intertidal seagrasses? Aquat Bot 87:161-6.

Sheridan P, McMahan G, Hammerstrom K, Pulich W. 1998. Factors affecting restoration of Halodule wrightii to Galveston bay, Texas. Restor Ecol 6:144-58.

Suykerbuyk W, Bouma TJ, van der Heide T, Faust C, Govers LL, Giesen WBJT, de Jong DJ, van Katwijk MM. 2012. Suppressing antagonistic bioengineering feedbacks doubles restoration success. Ecol Appl 22:1224-31.
Suykerbuyk W, Govers LL, Bouma TJ, Giesen WBJT, van der Voort R, de Jong DJ, Giesen K, Giesen PT, van Katwijk MM. (in press). Unpredictability in seagrass restoration: analysing the role of positive feedback and environmental stress on Zostera noltii transplants. J Appl Eco.

Suykerbuyk W, van Oven WG, Govers LL, Giesen K, Giesen WBJT, de Jong DJ, Bouma TJ, van Katwijk MM. (submitted). Living in the intertidal; desiccation reduces seagrass growth, but shading, high salinity or population of origin have no additional effect.

Temmerman S, Meire P, Bouma TJ, Herman PMJ, Ysebaert T, De Vriend HJ. 2013. Ecosystem-based coastal defence in the face of global change. Nature 504:79-83.

ten Brinke WBM, Dronkers J, Mulder JPM. 1994. Fine sediments in the Oosterschelde tidal basin before and after partial closure. Hydrobiologia 283:41-56.

van Breedveld JF. 1975. Transplanting of seagrass with emphasis on the importance of substrate. St. Petersburg: Florida Department of Natural Resources, Marine Research Laboratory.

Valdemarsen T, Wendelboe K, Egelund JT, Kristensen E, Flindt MR. 2011. Burial of seeds and seedlings by the lugworm Arenicola marina hampers eelgrass (Zostera marina) recovery. J Exp Mar Biol Ecol 410:45-52.

van der Heide T, Bouma TJ, van Nes EH, van de Koppel J, Scheffer M, Roelofs JGM, van Katwijk MM, Smolders AJP. 2010. Spatial self-organized patterning in seagrasses along a depth gradient of an intertidal ecosystem. Ecology 91:362-9.

van Katwijk MM, Hermus DCR. 2000. Effects of water dynamics on Zostera marina: transplantation experiments in the intertidal Dutch Wadden Sea. Mar Ecol Prog Ser 208:107-18.

van Keulen M, Paling EI, Walker CJ. 2003. Effect of planting unit size and sediment stabilization on seagrass transplants in Western Australia. Restor Ecol 11:50-5.

van Wesenbeeck BK, van de Koppel J, Herman PMJ, Bakker JP, Bouma TJ. 2007. Biomechanical warfare in ecology; negative interactions between species by habitat modification. Oikos 116:742-50.

Vermaat JE, Verhagen FCA. 1996. Seasonal variation in the intertidal seagrass Zostera noltii Hornem: coupling demographic and physiological patterns. Aquat Bot 52:259-81.

Waycott M, Duarte CM, Carruthers TJB, Orth RJ, Dennison WC, Olyarnik S, Calladine A, Fourqurean JW, Heck KL, Hughes AR, Kendrick GA, Kenworthy WJ, Short FT, Williams SL. 2009. Accelerating loss of seagrasses across the globe threatens coastal ecosystems. Proc Natl Acad Sci USA 106:12377-81.

Zhou Y, Liu P, Liu BJ, Liu XJ, Zhang XM, Wang F, Yang HS. 2014. Restoring eelgrass (Zostera marina L.) habitats using a simple and effective transplanting technique. Plos One 9:e92982.

Zipperle AM, Coyer JA, Reise K, Gitz E, Stam WT, Olsen JL. 2009. Clonal architecture in an intertidal bed of the dwarf eelgrass Zostera noltii in the Northern Wadden Sea: persistence through extreme physical perturbation and the importance of a seed bank. Mar Biol 156:2139-48. 